Professional Pedagogics/2(23)'2021, pp. $81-86$

IVT

THEORETICAL GROUNDS FOR THE DEVELOPMENT OF PROFES-SIONAL CULTURE OF PRODUCTION TRAINING MASTERS

\author{
Lilia Chohut ${ }^{1}$ \\ 1 Postgraduate Student at the Institute of VET of the NAES of Ukraine, Ukraine, \\ https://orcid.org/0000-0002-0994-4978, e-mail: chogutka@ukr.net
}

\begin{abstract}
.
The relevance of the study is determined by the affiliation of the training of teaching staff for vocational education (hereinafter: VE) to the priorities of the Framework of the State targeted social program for the development of vocational education for 2022-2027.

Objective: To provide a theoretical analysis of the problem of the development of professional culture and to clarify the conceptual and categorical apparatus of research.

Methods: study and analysis of philosophical, general scientific, methodological, psychological, and pedagogical literature, the legal framework, and educational and planning documentation - in order to determine the state of the problem; Synthesis of the information - obtained with the aim of defining research directions (clarification of hypothesis, conceptual apparatus); comparison - for comparison of the approaches of researchers to solving the problem of the formation and development of the concept of «professional culture»; synthesis - to support the conceptual-categorical apparatus of research.

Results: scientific literature, instructional-methodological, and legal documents have been studied; theoretical analysis of the development of «professional culture» pedagogical phenomenon problem has been performed; researchers' approaches to solving the formation and development of professional culture of the master of industrial training problem have been analyzed; the conceptual and categorical apparatus of research has been clarified.

Conclusions: in modern pedagogical science, the problem of training a highly educated, professional, and mobile specialist is a continuation not only of the national, but also of the world traditions of philosophical and pedagogical thought; the development of the professional culture of VE workers problem is not sufficiently represented in the country's scientific heritage (research is sparse, fragmented, and does not reflect a systemic view of the problem); «the professional culture of the master of industrial education» concept is defined as the integral quality of the individual, which contains a set of interrelated components (professional pedagogical self-awareness, pedagogical knowledge and professionally relevant key skills, pedagogical and professional experience, pedagogical values and convictions); and contributes to the achievement of success in professional pedagogical activities, domestic and professional communication, self-development and self-improvement of a specialist's personality, his or her continuous strive towards the pedagogical ethos.
\end{abstract}

Keywords: vocational education, professional culture, master of industrial education, self-education, pedagogical consciousness.

Introduction. Modernization of vocational education requires the establishment of a clear mechanism for improving the quality of training.

Professional Pedagogics / 2(23)'2021
The professional image of a pedagogical worker in a modern VE institution, his or her values, and professional culture are of great importance both 
for improving the quality of vocational education and for accelerating educational reforms in general. This is why the training of new types of vocational and pedagogical personnel for the modern vocational education system is stated as a priority in the Framework of the State targeted social program for the development of vocational education for 2022-2027 (Government portal: unified web portal of executive bodies of Ukraine, 2021).

Sources. In pedagogy and psychology, there has long been no systematic research on the phenomenon of master's professional culture. Many studies have covered its individual components: competence in communication (T. Hordon, Y. Yemelianov); intellectual and legal competence (O. Radkevych, M. Kholodna); social competence (V. Kunitsyna, R. Hintch, R. Ulrich); digital competence (O. Bazeliuk, V. Bykov, O. Humennyi, M. Yershov, A. Zuieva, A. Kononenko, L. Lypska, M. Pryhodii, O. Spiryn); pedagogical and foreign-speaking competence (L. Bazyl, S. Leu, L. Pukhovska), key competencies (H. Odnoroh, V. Radkevych); values and beliefs (O. Asmolov, L. Yershova, A. Kalenskyi, P. Luzan, $\quad$ V. Orlov); self-awareness (L. Bozhovych, I. Chesnokova). The theoretical and practical questions of the cultural approach to professional and pedagogical activity were uncovered by I. Androshchuk, I. Bashkirova, I. Kyiashko, V. Lola, S. Pryima, V. Nikitina. Some aspects of the professional culture of the educator are also presented in the publications by V. Radkevych, S. Brychok, L. Komisarovoi, S. Sysoievoi, V. Kovalchuka, O. Pavliuk, A. Rubtsovoi, and others. In a number of studies, the psychological culture of the personality is considered in the context of subjective experience of the person (L. Diomina, I. Ralnykova) and the age characteristics of its formation are studied (L. Kolmogorova, D. Kashyrskii). Research by scientists of the distance vocational training laboratory of the Institute of VET of the NAES of Ukraine, dedicated to the study of the methodological basis for the development of industrial education masters of VE institutions professional competence (Kruchek, 2021), is of great importance for the study of the peculiarities of the professional culture of industrial apprentices. At the same time, a holistic study of the development of the professional culture of industrial education masters problem, taking into account all the aspects of this problem, described in the works of the above-mentioned scientists and researchers, remains relevant.
The purpose of the article - to provide theoretical analysis of the development of professional culture problem and to clarify the conceptual and categorical apparatus of research.

Methods: study and analysis of philosophical, general scientific, methodological, psychological and pedagogical literature, the legal framework, and educational and planning documentation - in order to determine the state of the problem; Synthesis of the information obtained - with the aim of defining research directions (clarification of hypothesis, conceptual apparatus); comparison for comparison of the approaches of researchers to solving the problem of formation and development of the concept of «professional culture»; synthesis - to support the conceptual-categorical apparatus of research.

Results and discussion. Singling out pedagocical culture of masters of industrial education as a separate pedagogical phenomenon may be theoretically correct if one adheres to the views of philosophers and cultural scientists (L. Kohan, Y. Vyshnevskyi, V. Benin and others) that every human activity forms its own culture. Pedagogical culture, on one hand, is an element of general culture, a cross-cutting «subset» of society, and on the other - a special subsystem, a specific kind of culture with only its inherent characteristics. Identifying the professional culture of the master of industrial education as a phenomenon requires special attention due to specific nature of pedagogical activity and continuous increase in requirements of the master's personality. The professional culture of the Master of Industrial Training is based on sufficiently high industrial and technological experience, and it is a guarantee for the preservation of professional education workers category. A welldeveloped professional culture encourages masters to engage in permanent self-learning, selfdevelopment and self-education, which are the cross-cutting characteristics of an educator, and which will serve as a bright example of lifelong learning for the students. Professional culture is the guarantor of the preservation of the stock of professional and pedagogical workers among the experienced producers, as it contributes not only to the professional development of a specialist, but also to the personal development.

The high level of development of professional culture means that the master of industrial training is convinced of the true pedagogical methods, forms and methods of vocational training employed by him; he is therefore able to act independently and analyse the results of his activities. This is 
possible only if the apprentice has an established professional culture, which implies a certain pedagogical identity, pedagogical experience, and a system of values and beliefs. The leading link in this structure of professional culture of industrial training master is professional pedagogical selfawareness.

Thus, it can be argued that the professional culture of the master of industrial learning is an integral quality of the individual, containing a set of interrelated components (professional pedagogical consciousness, pedagogical knowledge and professionally relevant key skills, pedagogical and professional experience, pedagogical values and convictions) that contribute to the achievement of success in professional pedagogical activities, domestic and professional communication, selfdevelopment and self-improvement of the personality of a specialist, his or her continuous strive towards the pedagogical ethos.

Professional activity as a socio-cultural phenomenon has a complex structure, including goals, objectives, subject, means, methods, and results. The high level of professional culture of a specialist is characterized by the developed ability to solve professional tasks, that is, the developed professional thinking and consciousness. The components of a professional culture are axiological, technological and personal creativity.

Professional culture is the measure and method of creative self-realization of the personality of an industrial education master in VE institutions in various types of pedagogical activities and communication, aimed at mastering, transferring, and creating pedagogical values and technologies.

The axiological component of professional culture comprises a system of universal and professional values and a set of axiologically weighted vocational and educational knowledge and skills that are of great social and professional value and that act as pedagogical values.

The technological component of professional culture is the process by which a master of industrial education directly implements his or her vocational and pedagogical functions, performs his or her pedagogical tasks, formulates and achieves his or her pedagogical goals.

The personal and creative component of professional culture characterizes the personality of the apprentice as a subject of pedagogical activity endowed with pedagogical creativity and certain personal qualities (initiative, individual freedom, autonomy, responsibility, willingness to take risks, independence of judgement) and values (moral, aesthetic, legal, etc.) capable of building harmonious relations with oneself and the world, creating and developing oneself, influencing others in their professional activities in a good way (Popchuk, 2009).

Conclusions. It has been established that in modern pedagogical science the problem of training a highly educated, professional, and mobile specialist is a continuation not only of the national, but also of the world traditions of philosophical and pedagogical thought. It has been established that the problem of developing the professional culture of VE workers in the national scientific heritage is insufficiently represented (studies are few in number, fragmented, do not reflect a systemic view of the problem). The concept of the «professional culture of the master of industrial education» is defined as the integral quality of the individual, which contains a set of interrelated components (professional pedagogical selfawareness, pedagogical knowledge and professionally relevant key skills, pedagogical and professional experience, pedagogical values and convictions), contributing to the achievement of success in professional pedagogical activities, domestic and professional communication, selfdevelopment and self-improvement of the personality of a specialist, his continuous strive towards the pedagogical ethos. Further research will focus on the development of a model and methodology for the development of a professional culture of construction-related vocational training.

\section{List of references}

Базелюк О., 2018. Зміст і структура цифрової культури педагогічних працівників закладів професійної освіти. Науковий вісник Інституту професійно-технічної освіти НАПН України. Професійна педагогіка, 16, с. 81-87. DOI: http://doi.org/10.32835/2223-5752.2018.16.81-87.

Єршова, Л., 2015. Трансформація виховного ідеалу у вітчизняній педагогічній теорії і практиці (XIX-початок XX століття). Житомир: Свенок.

Єршова, Л., 2017. Макроекономічні фактори впливу на розвиток професійної кар'єри учнів професійно-технічних навчальних закладів. Науковий вісник Інституту професійно-технічної освіти НАПН України. Професійна педагогіка, 13, с. 22-29. 
Кручек, В. А. Кошук, О. Б. Кравець, С. Г. Майборода, Л. А. Пятничук, Т. В. Голуб, І. І. Самойленко, Н. Ю. та Однорог, Г. В., 2020. Методичні основи професійного навчання кваліфікованих робітників: методичний посібник. Житомир: Полісся.

Лузан, П., 2012. Реалізація компетентнісного підходу в професійній освіті: технологічний аспект. Науковий вісник Інституту професійно-технічної освіти НАПН Украӥни. Професійна педагогіка, 4, c. 5-11.

Лузан, П., Сопівник, І., та Виговська, С., 2012. Основи науково-педагогічних досліджень: навчальний посібник. К.: ДАКККіМ.

Михнюк, М. I, 2016. Теоретичні і методичні основи розвитку професійної культури викладачів спеціальних дисциплін будівельного профілю. Доктор наук. К.: Інститут професійно-технічної освіти НАПН України.

Попчук, О. В., 2009. Теоретичні аспекти дефініції феномена професійної культури. Наукові записки: Психологія і педагогіка, 13, с. С. 404-410.

Радкевич, В., 2012. Професійна компетентність - складова професійної культури. В: Педагогічна i психологічна науки в Украӥні: зб.н.пр. у 5 т. Т.4: Професійна освіта і освіта дорослих. С. 63-73.

Радкевич, В., 2020. Сучасні тенденції розвитку професійної освіти. В: Актуальні проблеми технологічної і професійної освіти. Міжнародна науково-практична конференція. Глухів, Україна, 14 Травень 2020 р. Глухів: Глухівський НПУ ім. О. Довженка.

Романова, Г.М. (ред.), Лузан, П.Г., Манько, В.М. та Нестерова, Л.В., 2014. Теорія і практика впровадження інновачійних технологій навчання у професійну підготовку кваліфікованих робітників. К.: ТОВ «НВП Поліграфсервіс».

Урядовий портал: єдиний веб-портал органів виконавчої влади України, 2021. Про схвалення Концепиії Державної изільової соичальної програми розвитку професійної (професійно-технічної) освіти на 2022-2027 роки: розпорядження Кабінету Міністрів від 09 грудня 2021 р., № 1619-р. Доступно: https://www.kmu.gov.ua/npas/pro-shvalennya-koncepciyi-derzhavnoyi-cilovoyi-socialnoyiprogrami-rozvitku-profesijnoyi-profesijno-tehnichnoyi-osviti-na-20222027-roki-1619-091221

(дата звернення 21 Грудень 2021)

Yershov, M.-O., 2020. Digitalization of general secondary education: issues and prospects. Zhytomyr Ivan Franko State University Journal. Pedagogical Sciences, 4(103), p. 19-27. https://doi.org/10.37472/2707-305X-2020-2-1-8-1.

\section{Translated \& Transliterated}

Bazeliuk O., 2018. Zmist i struktura tsyfrovoi kultury pedahohichnykh pratsivnykiv zakladiv profesiinoi osvity [Content and structure of digital culture of the teaching staff at vocational schools]. Naukovyi visnyk Instytutu profesiino-tekhnichnoi osvity NAPN Ukrainy. Profesiina pedahohika [Scientific Herald of the Institute of Vocational Education and Training of the National Academy of Pedagogical Sciences of Ukraine. Vocational pedagogy], 16, s. 81-87. DOI: http://doi.org/10.32835/2223-5752.2018.16.81-87, [in Ukrainian].

Yershova, L., 2015. Transformatsiia vykhovnoho idealu u vitchyznianii pedahohichnii teorii $i$ praktytsi (XIX-pochatok XXI stolittia) [Transformation of the educational ideal in the native pedagogical theory and practice (XIX - the beginning of XX century)]. Zhytomyr: Yevenok, [in Ukrainian].

Yershova, L., 2017. Makroekonomichni faktory vplyvu na rozvytok profesiinoi kariery uchniv profesiino-tekhnichnykh navchalnykh zakladiv [Macroeconomic factors of influence on professional career development of vet institutions students]. Naukovyi visnyk Instytutu profesiino-tekhnichnoi osvity NAPN Ukrainy. Profesiina pedahohika [Scientific herald of the Institute of Vocational Education APN of Ukraine. Professional Pedagogy], 13, s. 22-29,_[in Ukrainian].

Kruchek, V. A. Koshuk, O. B. Kravets, S. H. Maiboroda, L. A. Piatnychuk, T. V. Holub, I. I. Samoilenko, N. Yu. ta Odnoroh, H. V., 2020. Metodychni osnovy profesiinoho navchannia kvalifikovanykh robitnykiv: metodychnyi posibnyk [Methodical bases of professional training of skilled workers: methodical manual]. Zhytomyr: Polissia,_[in Ukrainian].

Luzan, P., 2012. Realizatsiia kompetentnisnoho pidkhodu v profesiinii osviti: tekhnolohichnyi aspekt [Realization of competency approach at a higher school: technological aspect]. Naukovyi visnyk Instytutu 
profesiino-tekhnichnoi osvity NAPN Ukrainy. Profesiina pedahohika [Scientific herald of the Institute of Vocational Education APN of Ukraine. Professional Pedagogy], 4, s. 5-11, [in Ukrainian].

Luzan, P., Sopivnyk, I., ta Vyhovska, S., 2012. Osnovy naukovo-pedahohichnykh doslidzhen: navchalnyi posibnyk [Fundamentals of scientific and pedagogical research: a textbook]. K.: DAKKKiM, [in Ukrainian].

Mykhniuk, M. I, 2016. Teoretychni i metodychni osnovy rozvytku profesiinoi kultury vykladachiv spetsialnykh dystsyplin budivelnoho profiliu [Theoretical and methodological bases of development of professional culture of teachers of special disciplines of construction profile]. Doktor nauk. K.: Instytut profesiino-tekhnichnoi osvity NAPN Ukrainy [Institute of Vocational Education and Training of NAES of Ukraine], [in Ukrainian].

Popchuk, O. V., 2009. Teoretychni aspekty definitsii fenomena profesiinoi kultury [Theoretical aspects of the definition of the phenomenon of professional culture]. Naukovi zapysky: Psykholohiia i pedahohika [Scientific notes: Psychology and pedagogy], 13, s. S. 404-410, [in Ukrainian].

Radkevych, V., 2012. Profesiina kompetentnist - skladova profesiinoi kultury [Professional competence - component of professional culture]. V: Pedahohichna i psykholohichna nauky v Ukraini [Pedagogical and psychological sciences in Ukraine]: zb.n.pr. u 5 t. T.4: Profesiina osvita i osvita doroslykh [Vocational and adult education]. S. 63-73.

Radkevych, V., 2020. Suchasni tendentsii rozvytku profesiinoi osvity [Modern trends in the development of vocational education]. V: Aktualni problemy tekhnolohichnoi i profesiinoi osvity. Mizhnarodna naukovo-praktychna konferentsiia [Current topics of technological and vocational education. International scientific and practical conference]. Hlukhiv, Ukraina, 14 Traven 2020 r. Hlukhiv: Hlukhivskyi NPU im. O. Dovzhenka, [in Ukrainian].

Romanova, H.M. (red.), Luzan, P.H., Manko, V.M. ta Nesterova, L.V., 2014. Teoriia i praktyka vprovadzhennia innovatsiinykh tekhnolohii navchannia u profesiinu pidhotovku kvalifikovanykh robitnykiv [Theory and practice of introducing innovative learning technologies in the training of skilled workers]. K.: TOV «NVP Polihrafservis», [in Ukrainian].

Uriadovyi portal: yedynyi veb-portal orhaniv vykonavchoi vlady Ukrainy, 2021. Pro skhvalennia Kontseptsii Derzhavnoi tsilovoi sotsialnoi prohramy rozvytku profesiinoi (profesiino-tekhnichnoi) osvity na 2022-2027 roky: rozporiadzhennia Kabinetu Ministriv vid 09 hrudnia 2021 r., № 1619-r. [On approval of the Framework of the State target social program for the development of vocational (technical) education for 2022-2027: order of the Cabinet of Ministers of December 9, 2021, № 1619-p]. Dostupno: https://www.kmu.gov.ua/npas/pro-shvalennya-koncepciyi-derzhavnoyi-cilovoyi-socialnoyi-programirozvitku-profesijnoyi-profesijno-tehnichnoyi-osviti-na-20222027-roki-1619-091221 (data zvernennia 21 Hruden 2021), [in Ukrainian].

Yershov, M.-O., 2020. Digitalization of general secondary education: issues and prospects. Zhytomyr Ivan Franko State University Journal. Pedagogical Sciences, 4(103), p. 19-27. https://doi.org/10.37472/2707-305X-2020-2-1-8-1, [in English]. 


\title{
ТЕОРЕТИЧНІ ОСНОВИ РОЗВИТКУ ПРОФЕСІЙНОЇ КУЛЬТУРИ МАЙСТРІВ ВИРОБНИЧОГО НАВЧАННЯ
}

\author{
Лілія Чогут ${ }^{1}$ \\ 1 аспірантка Інституту професійно-технічної освіти НАПН України, Україна, \\ https://orcid.org/0000-0002-0994-4978, e-mail: chogutka@ukr.net
}

\section{Реферат.}

Актуальність дослідження визначається приналежністю проблеми підготовки педагогічних кадрів для системи професійної (професійно-технічної) освіти (далі: П(ПТ)О) до пріоритетних завдань Концепції Державної цільової соціальної програми розвитку професійної (професійно-технічної) освіти на 2022-2027 роки.

Meта: здійснити теоретичний аналіз проблеми розвитку професійної культури та уточнити поняттєвокатегоріальний апарат дослідження.

Методи: вивчення й аналіз філософської, загальнонаукової, методичної, психолого-педагогічної літератури, нормативно-правової бази, навчально-плануючої документації - для виявлення стану розробленості проблеми; узагальнення одержаної інформації - 3 метою визначення напрямів дослідження (уточнення гіпотези, поняттєвого апарату); порівняння, зіставлення - для порівняння підходів дослідників до розв'язання проблеми формування й розвитку поняття «професійна культура»; синтез - для обгрунтування поняттєвокатегоріального апарату дослідження.

Результати: вивчено наукову літературу та інструктивно-методичні й нормативно-правові документи; здійснено теоретичний аналіз проблеми розвитку педагогічного феномена «професійна культура»; проаналізовано підходи дослідників до розв'язання проблеми формування і розвитку професійної культури майстра виробничого навчання; уточнено поняттєво-категоріальний апарат дослідження.

Висновки: у сучасній педагогічній науці проблема підготовки високоосвіченого, професійного і мобільного фахівця є продовженням не лише вітчизняних, а й світових традицій філософської та педагогічної думки; проблема розвитку професійної культури майстрів виробничого навчання закладів П(ПТ)О у вітчизняному науковому доробку представлена не достатньо (дослідження нечисленні, фрагментарні, не відображають системного бачення проблеми); поняття «професійна культура майстра виробничого навчання» визначено як інтегральна якість особистості, що містить сукупність взаємопов'язаних компонентів (професійна педагогічна самосвідомість, педагогічні знання та професійно актуальні ключові навички, педагогічний і професійний досвід, педагогічні цінності й переконання), які сприяють досягненню успіху у професійній педагогічної діяльності, побутовому та професійному спілкуванні, саморозвитку і самовдосконаленні особистості фахівця, його невпинному рухові до педагогічного ідеалу.

Ключові слова: професійна освіта, професійна культура, майстер виробничого навчання, самоосвіта, педагогічна самосвідомість. 